\title{
A Review of Viral Shedding in Resolved and Convalescent COVID-19 Patients
}

\author{
Rutu Karia $^{1}$ (D) Sanjana Nagraj ${ }^{2}$ \\ Accepted: 28 August 2020 / Published online: 3 September 2020 \\ (C) Springer Nature Switzerland AG 2020
}

\begin{abstract}
As of August 06, 2020, 18.9 million cases of SARS-CoV-2 and more than 711,000 deaths have been reported. As per available data, $80 \%$ of the patients experience mild disease, $20 \%$ need hospital admission, and about $5 \%$ require intensive care. To date, several modes of transmission such as droplet, contact, airborne, blood borne, and fomite have been described as plausible. Several studies have demonstrated shedding of the virus from patients after being free from symptoms, i.e. prolonged virus shedding. While few studies demonstrated virus shedding in convalescent patients, i.e. those testing negative for presence of virus on nasopharyngeal and/or oropharyngeal swabs, yet virus shedding was reported from other sources. Maximum duration of conversion time reported among the included studies was 60 days, while the least duration was 3 days. Viral shedding from sources other than nasopharynx and oropharynx, like stools, urine, saliva, semen, and tears, was reported. More number of studies described virus shedding from gastrointestinal tract (mainly in stools), while least a number of cases tested positive for the virus in tears. Prolonged viral shedding is important to consider while discontinuing isolation procedures and/or discharging SARS-CoV2 patients. The risk of transmission varies in magnitude and depends on the infectivity of the shed virus in biological samples and the patient population involved. Clinical decision-making should be governed by clinical scenario, guidelines, detectable viral load, source of detectable virus, infectivity, and patient-related factors.
\end{abstract}

Keywords Prolonged shedding $\cdot$ Virus shedding $\cdot$ Convalescent patients $\cdot$ Transmission

\section{Introduction}

As of August 06, 2020, 18.9 million cases of SARS-CoV-2 and more than 711,000 deaths have been reported. As per available data, $80 \%$ of the patients experience mild disease, $20 \%$ need hospital admission, and about $5 \%$ require intensive care [1]. To date, several modes of transmission such as droplet, contact, airborne, blood borne, and fomite have been described as plausible [2]. Asymptomatic carrier transmission of the virus has been demonstrated in several studies, highlighting the importance of identifying the sources of transmission and breaking the chain [3-5]. Viable SARS-CoV-2 has been

Topical Collection on COVID-19

Rutu Karia

rutu.karia@gmail.com

1 Anna Medical College and Research Center, Montagne Blanche, Mauritius

2 Internal Medicine, Jacobi Medical Center/Albert Einstein College of Medicine, New York, NY, USA detected in several biological samples such as faeces, urine, and blood. These biological specimens are of key interest as they can serve as sources of transmission and as targets for breaking the transmission chain [6-8]. With the emergence of new data, guidelines and clinical practice are constantly evolving in an effort to mitigate the disease burden of this global health crisis. In this study, we aim to study the sources of viral shedding that have been reported to date and compare the duration of shedding from different sources and their relation to clinical recovery. We also aim to highlight the importance of viral shedding in clinical decision-making about discontinuation of isolation procedures.

\section{Methodology}

\section{Search Method and Strategy}

We conducted a literature search during the months of June and July 2020 for articles on the various modes through which the virus may be shed from the affected host and may lead to 
transmission of COVID-19 infection. The Preferred Reporting Items for Systematic Reviews and Meta-Analyses (PRISMA) guidelines were used for selection of studies [9]. Primary databases that were used for the search are WHO, PubMed, and Google Scholar. The search strategy used the following keywords: shedding, convalescent, prolonged, coronavirus, COVID-19, and their combination.

\section{Data Screening and Eligibility}

The final review articles fulfilled the following criteria:

1. Reported duration of viral shedding and its source in patients with resolved clinical symptoms but testing positive for SARS-CoV2 (prolonged viral shedding)

2. Reported viral shedding and its source in convalescent patients

3. Included patient data regardless of age, gender, or location

4. Full text, peer-reviewed articles

5. Articles in English

Articles that did not contain patient data or studies pertaining to SARS-CoV-1 and MERS were excluded. In doing so, we had 19 articles for the final review (Table 1). Each paper was reviewed by both the authors independently, and disagreements were discussed and resolved via a consensus.

Prolonged viral shedding was defined as persistently testing positive for SARS-CoV2 RNA despite resolution of clinical symptoms and radiological findings, i.e. viral shedding for more than the expected number of days. The virus may be found in nasopharyngeal and/or oropharyngeal swabs or other routes of viral shedding like faeces, urine, saliva, semen, and tears. Convalescent patients were defined as recovered cases testing negative for SARS-CoV2 in nasopharyngeal and/or oropharyngeal swabs yet shedding the virus from other routes.

\section{Data Collection and Analysis}

Data was collected in the following categories when available:

1. Patient demographics

2. Risk factors for prolonged viral shedding

3. Viral load in different body fluids and secretions

Our review included studies from various countries from across the globe. The studies used have been listed in Table 1 .

We tabulated the data using Microsoft Excel. Referencing was done according to guidelines using Zotero.

This study did not require ethical approval as data was obtained from already available databases, and patients were not directly involved.
Assessing Risk of Bias and Quality of the Articles

Both the authors independently assessed the risk of bias for each of the studies included. Authors resolved disagreements by a consensus. The NIH Quality Assessment Tool was used to assess the quality of case series/case reports (Table 4) [29]. The New Castle-Ottawa Quality Assessment Scale was used for assessing the quality of cohort studies and was rated as good, fair, or poor (Table 5) [30].

\section{Results}

Of the 313 manuscripts retrieved from our search, 19 studies were found eligible and considered for data extraction (Fig. 1).

Studies reporting duration of virus shedding and its source(s) in patients with resolved symptoms and/or in convalescent patients were included and reviewed (Table 1). Patients shedding virus after being free from symptoms were said to have prolonged virus shedding. Convalescent patients were defined as patients testing negative for presence of virus on nasopharyngeal and/or oropharyngeal swabs, yet virus shedding was reported from other sources. Various sources of viral shedding are summarized in Fig. 2.

The number of days of viral shedding varied among the included studies and among the included patients. Thus, the studies reported the duration as either total number of days or median or mean number of days of virus shedding from the onset of illness to testing negative (conversion time) (Table 2). Maximum duration of conversion time among the included studies was reported by Li et al., which was 60 days [12]. Followed by 44 days of conversion time reported by $\mathrm{Fu}$ et al. Interestingly, the least duration of conversion time noted was 3 days [13].

Samples from nasopharynx and/or oropharynx are commonly considered for testing SARS-CoV-2 RNA, while a few studies also reported shedding of virus from sources other than nasopharynx and oropharynx, for example, stools, urine, saliva, semen, and tears (Table 3). More number of studies described virus shedding from gastrointestinal tract (mainly in stools), while a least number of cases tested positive for the virus in tears.

Few studies reported probable risk factors that may favour delayed clearance of the virus. Qi et al. demonstrated that the time from symptom onset to admission and the length of hospital stay may be risk factors for prolonged virus shedding [10]. Fu et al. studied clearance in patients with coronary heart disease (CHD) and reported that decreased albumin levels and delayed antiviral therapy may delay clearance of virus [13]. Patients with albumin $\geq 35 \mathrm{~g} / \mathrm{L}$ had a shorter duration of viral RNA shedding compared with those with albumin $<35 \mathrm{~g} / \mathrm{L}$, and the median times were 18 days and 20 days, respectively. Campioli et al. and Decker et al. suggested that the 
Table 1 Summary of included studies

\begin{tabular}{llll}
\hline Author Country & Study design & $\begin{array}{l}\text { Number of } \\
\text { included } \\
\text { patients }\end{array}$ & $\begin{array}{l}\text { Source of viral Results/conclusion of the study } \\
\text { shedding } \\
\text { studied }\end{array}$ \\
\hline
\end{tabular}

\begin{tabular}{|c|c|c|c|c|}
\hline Qi et al. & China & $\begin{array}{l}\text { Retrospective } \\
\text { cohort }\end{array}$ & 147 & Nasopharynx \\
\hline Campioli et al. & USA & $\begin{array}{l}\text { Retrospective } \\
\text { cohort }\end{array}$ & 251 & Nasopharynx \\
\hline Li et al. & China & Case report & 1 & $\begin{array}{l}\text { Nasopharynx } \\
\text { and } \\
\text { oropharyn }\end{array}$ \\
\hline Fu et al. & China & $\begin{array}{l}\text { Prospective } \\
\text { cohort }\end{array}$ & 410 & Oropharynx \\
\hline
\end{tabular}

Decker et al. Germany Case report 1 Oropharynx

The time from symptom onset to admission (OR* 1.740; 95\% CI 1.29; $p<0.001$ ) and the hospital length of stay (OR 1.604; 95\% CI* 1.26; $\mathrm{p}<0.001$ ) were found to be risk factors for a prolonged duration of viral shedding of more than 17 days

Risk factors for delayed cessation of virus shedding included asthma and immunosuppression. The cumulative cessation of virus shedding rate at 2 weeks from symptom onset was $13.5 \%$, and increased to $43.8 \%$ at 3 weeks, suggesting that testing after 3 weeks of symptoms might have a greater rate of cessation of virus shedding

Viral shedding seen for 60 days from illness onset. Persistent viral shedding was noted for 36 days after resolution of symptoms

Risk factors for delayed clearance of SARS-CoV-2 RNA included patients with $\mathrm{CHD}^{*}$, decreased albumin levels, and delayed antiviral therapy. Patients with albumin $\leq 35 \mathrm{~g} / \mathrm{L}$ had prolonged viral shedding with a median of 20 days

\begin{tabular}{|c|c|c|c|c|}
\hline Ling et al. & China & $\begin{array}{l}\text { Retrospective } \\
\text { cohort }\end{array}$ & 66 & $\begin{array}{l}\text { Oropharynx, } \\
\text { stools, urin }\end{array}$ \\
\hline Zhang et al. & China & Case Series & 23 & $\begin{array}{r}\text { Nasopharynx, } \\
\text { stools, urin }\end{array}$ \\
\hline Lo et al. & China & $\begin{array}{l}\text { Prospective } \\
\text { cohort }\end{array}$ & 10 & $\begin{array}{c}\text { Nasopharynx } \\
\text { and stools }\end{array}$ \\
\hline Xing et al. & China & $\begin{array}{l}\text { Prospective } \\
\text { cohort }\end{array}$ & 3 & Stools \\
\hline Hosoda et al. & Japan & Case Report & 1 & Stools \\
\hline Zhao et al. & China & $\begin{array}{l}\text { Retrospective } \\
\text { cohort }\end{array}$ & 401 & Rectal swab \\
\hline Wu et al. & China & $\begin{array}{c}\text { Prospective } \\
\text { cohort }\end{array}$ & 74 & Stools \\
\hline
\end{tabular}

20 days after initial presentation, the patient was asymptomatic, but virus culture of throat swabs on days 18,21 , and 35 had viral copy numbers similar to the onset of infection Immunosuppressive therapy may contribute to delayed clearance of virus

Clearance of viral RNA from patients' stools was delayed compared with that from oropharyngeal swabs by 2 days. Mean number of days of clearance of virus from pharynx was 9.5 days, while from stools was 11 days. Viral nucleic acid was also found in urine

A longer virus shedding period was found in the faecal samples (median 22.0 days) compared with the upper respiratory samples (median 10.0 days). However, the viral RNA in the latter were generally detectable earlier than in the former. Urine samples of two critically ill patients were positive for viral RNA

Average viral RNA conversion time (in days) for nasopharyngeal swab was 18.2 , while for faeces was 19.3

SARS-CoV-2 may exist in the gastrointestinal tract for a longer time than the respiratory tract with a greater load in cases

Patient even after recovering from acute enterocolitis due to SARS-CoV-2 continued to excrete the virus in stools for weeks

Prolonged viral shedding in faeces with higher positive rate and higher viral load than the paired respiratory samples. The longest duration observed was 43 days

Average viral RNA conversion time (in days) for nasopharyngeal swab was 16.7 while for faeces was 27.9. Possibility of prolonged viral shedding in faeces, for nearly 5 weeks after the patients' respiratory samples tested negative for SARS-CoV-2 RNA

\begin{tabular}{|c|c|c|c|c|}
\hline Xu et al. & China & $\begin{array}{l}\text { Prospective } \\
\text { cohort }\end{array}$ & 8 & Rectal swab \\
\hline Huang et al. & China & Case Series & 1 & $\begin{array}{l}\text { Oropharynx } \\
\text { and anal } \\
\text { swabs }\end{array}$ \\
\hline Ren et al. & China & Case Report & 1 & Urine \\
\hline Azzi et al. & Italy & $\begin{array}{l}\text { Prospective } \\
\text { cohort }\end{array}$ & 25 & $\begin{array}{l}\text { Nasopharynx } \\
\text { and saliva }\end{array}$ \\
\hline Li et al. & China & $\begin{array}{l}\text { Prospective } \\
\text { cohort }\end{array}$ & 6 & Semen \\
\hline Valente et al. & Italy & & 3 & Tears \\
\hline
\end{tabular}

Viral shedding from the digestive system might be greater and last longer than that from the respiratory tract

The SARS-CoV-2 nucleic acid became negative in throat swab samples, while the anal swab samples continued to be positive for at least 9 days

The urine of asymptomatic patients was tested positive, while RT-PCR of throat swab was negative

Initially, all 25 cases tested positive for viral RNA in saliva and nasopharyngeal swab. Later, saliva was tested positive in 2 patients, while nasopharyngeal swab tested negative

Six cases tested positive. Four patients $(26.7 \%)$ were in the acute stage of infection, and 2 patients $(8.7 \%)$ were recovering 
Table 1 (continued)

\begin{tabular}{|c|c|c|c|c|c|}
\hline Author & Country & Study design & $\begin{array}{l}\text { Number of } \\
\text { included } \\
\text { patients }\end{array}$ & $\begin{array}{l}\text { Source of viral } \\
\text { shedding } \\
\text { studied }\end{array}$ & Results/conclusion of the study \\
\hline & & $\begin{array}{l}\text { Prospective } \\
\text { cohort }\end{array}$ & & & $\begin{array}{l}\text { Despite the low prevalence and rapid regression of viral presence in the } \\
\text { conjunctiva, SARS-CoV-2 transmission through tears may be } \\
\text { possible, even in patients without apparent ocular involvement }\end{array}$ \\
\hline $\begin{array}{l}\text { Güemes-Villahoz } \\
\text { et al. }\end{array}$ & Spain & $\begin{array}{l}\text { Prospective } \\
\text { cohort }\end{array}$ & 1 & Tears & $\begin{array}{l}\text { The detection of SARS-CoV-2 RNA in tears and conjunctival swabs } \\
\text { highlights the role of the eye as a possible route of transmission of the } \\
\text { disease }\end{array}$ \\
\hline
\end{tabular}

* OR odds ratio, $C I$ confidence interval, $S A R S-C o V-2$ severe acute respiratory syndrome coronavirus 2, CHD coronary heart disease, $R T-P C R$ reverse transcription polymerase chain reaction, $R N A$ ribonucleic acid [10-28]

immunosuppressive therapy may contribute to delayed clearance of virus $[11,14]$. In addition, Campioli et al. suggested that asthma may be a cause of delayed recovery.

The qualitative assessment of the included studies was performed. The NIH Quality Assessment Tool was used to assess the quality of case series/case reports (Table 4) [29]. The New Castle-Ottawa Quality Assessment Scale was used for assessing the quality of cohort studies and was rated as good, fair, or poor (Table 5) [30].

\section{Discussion}

In the interim guidance for the clinical management of COVID19, the World Health Organization (WHO) outlined the discharge criteria by taking prolonged viral shedding and its implication in infectivity and community transmission into consideration [31]. Two negative RT-PCR results on sequential samples taken at least $24 \mathrm{~h}$ apart and clinical recovery are no longer required to meet the criteria for discharge from a healthcare
Fig. 1 Preferred Reporting Items for Systematic Reviews and Meta-Analyses (PRISMA) flowchart
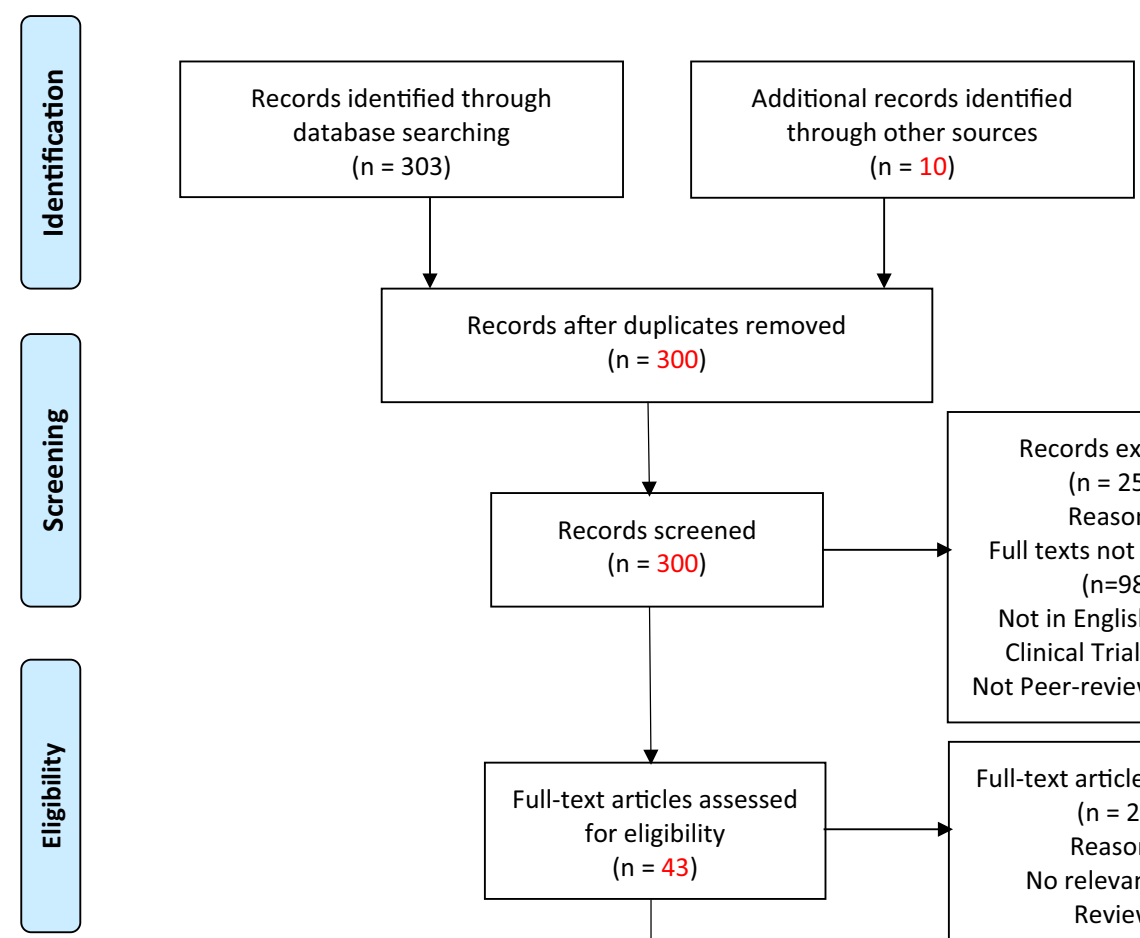
$(n=303)$

$$
(n=10)
$$
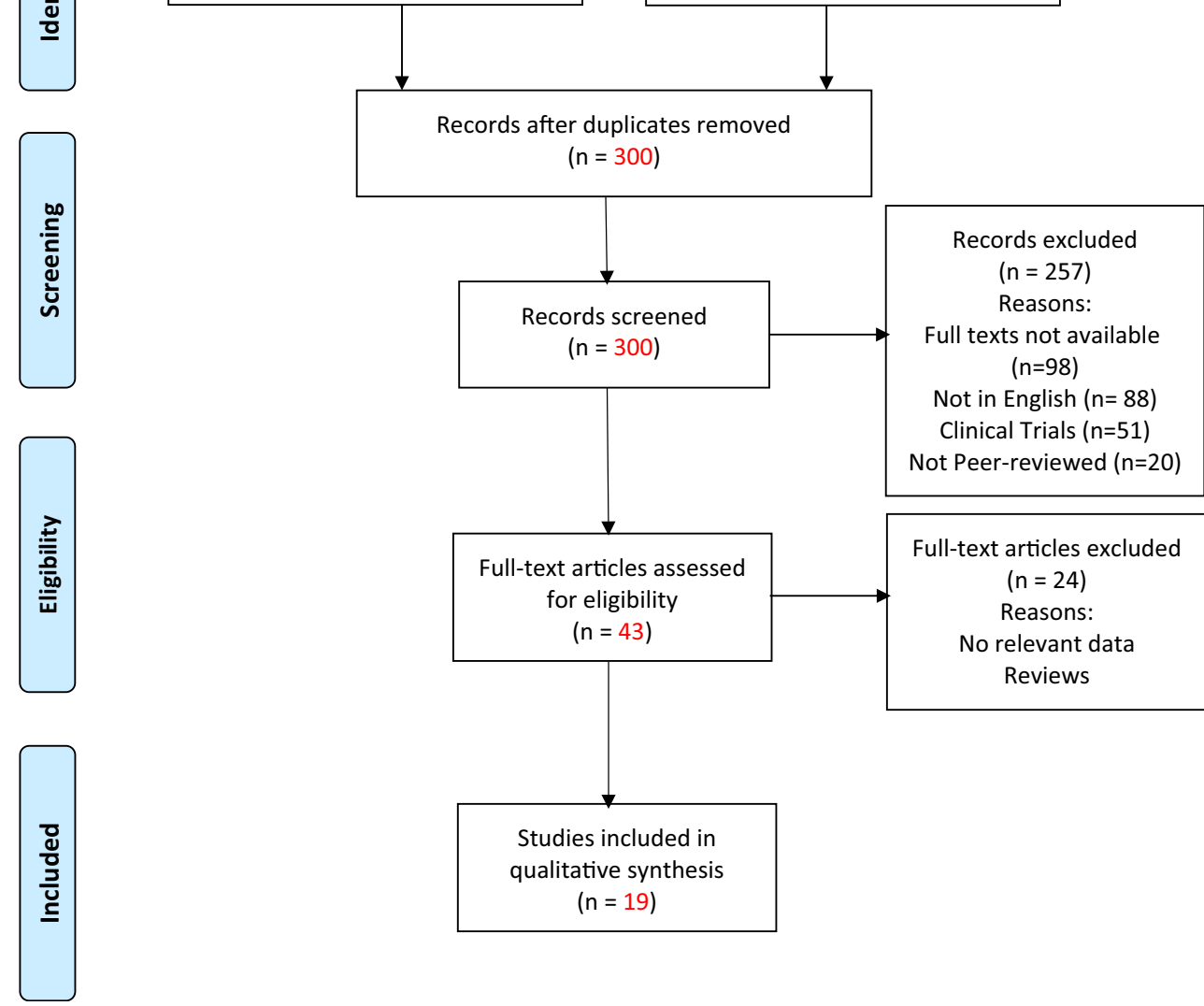
Fig. 2 Modes of virus shedding

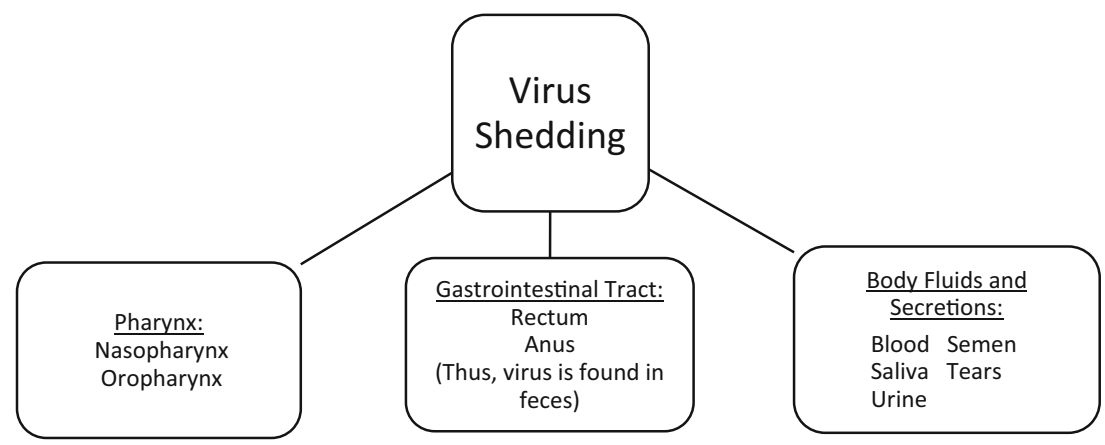

facility or isolation $[31,32]$. Factoring insufficient testing capacity, economic strain, access to healthcare, and variable test results based on prolonged viral shedding, the WHO revised its criteria for discontinuing transmission-based precautions without requiring retesting [33]. As per the updated recommendations, symptomatic patients can be discharged 10 days after the first day of symptom onset, plus a minimum of 3 days without symptoms. Asymptomatic patients can be released from isolation measures 10 days after the first positive test for SARS-CoV-2 [31].

Our review identified the nasopharynx and oropharynx as the most commonly tested sources for detecting viral shedding. Other sources included stool/anal swab/rectal swab, saliva, urine, tears, and semen. Interestingly, in 69 patients from 10 of our included studies, SARS-CoV-2 was detected in an alternative source, while the most common sources such as oropharyngeal or nasopharyngeal swabs were negative [15-19, 21-25].
In our review, immunosuppressive therapy was identified as a possible contributing factor for delayed clearance of the virus $[11,14]$. Similarly, Zhu et al. reported prolonged detection of viral RNA in immunosuppressed renal transplant patients [34]. However, this study used RT-PCR of throat swabs as its mode of virus detection, a mode that does not necessarily translate to viral replication. In our study, Decker et al. identified that 20 days after initial presentation, viral culture of throat swabs on days 18,21 , and 35 had viral copy numbers similar to the onset of infection despite clinical recovery [14]. Of note, viral culture can serve as an identifier of infectivity as it detects the ability of the virus to replicate and, thus, produce disease upon community transmission. Although RT-PCR does not provide information about the virus' ability to replicate, it is more sensitive than viral culture, and studies have reported viable virus in asymptomatic patients who tested positive by this methodology [31, 35-37]. In high-risk

Table 2 Studies reporting duration of virus shedding

\begin{tabular}{|c|c|c|}
\hline Study & Source of virus shedding & Duration of virus shedding reported \\
\hline Qi et al. & Nasopharynx & $\begin{array}{l}\text { Median days of viral shedding: } 17 \text { days }\left(\mathrm{IQR}^{*}, 12-21\right) \\
\text { Shortest duration: } 6 \text { days } \\
\text { Longest duration: } 47 \text { days }\end{array}$ \\
\hline Li et al. & Nasopharynx and/or oropharynx & $\begin{array}{l}\text { Total number of days: } 60 \text { days } \\
\text { After resolution of symptoms: } 36 \text { days }\end{array}$ \\
\hline Fu et al. & Oropharynx & $\begin{array}{l}\text { Median days of viral shedding: } 19 \text { days (IQR, 16-23) } \\
\text { Shortest duration: } 3 \text { days } \\
\text { Longest duration: } 44 \text { days }\end{array}$ \\
\hline Decker et al. & Oropharynx & After resolution of symptoms: 15 days \\
\hline Ling et al. & $\begin{array}{l}\text { Oropharynx } \\
\text { Stools }\end{array}$ & $\begin{array}{l}\text { Mean number of days: } 9.5 \text { days } \\
\text { Mean number of days: } 11 \text { days }\end{array}$ \\
\hline Zhang et al. & $\begin{array}{l}\text { Nasopharynx } \\
\text { Stools }\end{array}$ & $\begin{array}{l}\text { Median days of viral shedding: } 10.0 \text { days (IQR, 8.0-17.0). } \\
\text { Median days of viral shedding: } 22.0 \text { days (IQR, 15.5-23.5). }\end{array}$ \\
\hline Lo et al. & $\begin{array}{l}\text { Nasopharynx } \\
\text { Stools }\end{array}$ & $\begin{array}{l}\text { Mean number of days: } 18.2 \text { days } \\
\text { Mean number of days: } 19.3 \text { days }\end{array}$ \\
\hline Xing et al. & Stools & Mean number of days: 16 days \\
\hline Hosoda et al. & Stools & Total number of days: 15 days \\
\hline Wu et al. & $\begin{array}{l}\text { Nasopharynx } \\
\text { Stools }\end{array}$ & $\begin{array}{l}\text { Mean number of days: } 16.7 \text { days } \\
\text { Mean number of days: } 27.9 \text { days }\end{array}$ \\
\hline
\end{tabular}

*IQR interquartile range [10, 12-19, 21] 
Table 3 Studies reporting number of patients testing positive for other source of shedding

\begin{tabular}{|c|c|c|c|}
\hline Study & Other source of viral shedding & $\begin{array}{l}\text { NPS/OPS* positive } \\
+ \\
\text { other source (s) positive }\end{array}$ & $\begin{array}{l}\text { NPS/OPS negative but } \\
\text { other source(s) was still positive }\end{array}$ \\
\hline \multirow[t]{2}{*}{ Ling et al. } & Stools & 66 & 11 \\
\hline & Urine & 4 & 3 \\
\hline \multirow[t]{2}{*}{ Zhang et al. } & Stools & 10 & 3 \\
\hline & Urine & 2 & - \\
\hline Lo et al. & Stools & 10 & 5 \\
\hline Xing et al. & Stools & 3 & 2 \\
\hline Hosoda et al. & Stools & - & 1 \\
\hline Wu et al. & Stools & 41 & 32 \\
\hline $\mathrm{Xu}$ et al. & Rectal swab & 8 & 8 \\
\hline Huang et al. & Anal swab & 1 & 1 \\
\hline Ren et al. & Urine & - & 1 \\
\hline Azzi et al. & Saliva & 25 & 2 \\
\hline Li et al. & Semen & 6 & - \\
\hline Valente et al. & Tears & 3 & - \\
\hline Güemes-Villahoz et al. & Tears & 1 & - \\
\hline
\end{tabular}

*NPS nasopharyngeal swab, OPS oropharyngeal swab [15-19, 21-28]

populations such as immunocompromised patients or patients interacting with vulnerable groups, the WHO encourages laboratory testing guided discharge and/or discontinuation of isolation procedures [31].

In several of our included studies, viral shedding was detected from the gastrointestinal tract for a longer duration and at a greater viral load than from the respiratory tract [16-18, 20-23]. Similar results were reported in a study of 73 COVID-
19 patients from China, whereby $>20 \%$ of infected patients tested positive for the virus in the faeces even after clearance of the virus from their respiratory tracts [38]. In a metaanalysis of 4805 COVID-19 patients, Parasa et al. concluded that feco-oral route of transmission is possible due to the presence of Viral RNA in stool [39]. Therefore, gastrointestinal tract can possibly serve as an important source of community transmission of SARS-CoV2. Further studies to determine the

Table 4 NIH quality assessment tool for case series/case reports

\begin{tabular}{|c|c|c|c|c|c|c|c|c|c|c|}
\hline Author & $\begin{array}{l}\text { Was the study } \\
\text { question or } \\
\text { objective } \\
\text { clearly stated? }\end{array}$ & $\begin{array}{l}\text { Was the } \\
\text { study } \\
\text { population } \\
\text { clearly and } \\
\text { fully } \\
\text { described, } \\
\text { including a } \\
\text { case } \\
\text { definition? }\end{array}$ & $\begin{array}{l}\text { Were the } \\
\text { cases } \\
\text { consecutive? }\end{array}$ & $\begin{array}{l}\text { Were the } \\
\text { subjects } \\
\text { comparable? }\end{array}$ & $\begin{array}{l}\text { Was the } \\
\text { intervention } \\
\text { clearly } \\
\text { described? }\end{array}$ & $\begin{array}{l}\text { Were the } \\
\text { outcome } \\
\text { measures } \\
\text { clearly } \\
\text { defined, } \\
\text { valid, } \\
\text { reliable, and } \\
\text { implemented } \\
\text { consistently } \\
\text { across all } \\
\text { study } \\
\text { participants? }\end{array}$ & $\begin{array}{l}\text { Was the } \\
\text { length of } \\
\text { follow-up } \\
\text { adequate? }\end{array}$ & $\begin{array}{l}\text { Were the } \\
\text { statistical } \\
\text { methods } \\
\text { well } \\
\text { described? }\end{array}$ & $\begin{array}{l}\text { Were the } \\
\text { results } \\
\text { well } \\
\text { described? }\end{array}$ & $\begin{array}{l}\text { Quality } \\
\text { rating } \\
\text { (good, } \\
\text { fair, } \\
\text { poor) }\end{array}$ \\
\hline Li et al. & Yes & Yes & N/A* & N/A & Yes & Yes & Yes & $\mathrm{N} / \mathrm{R}^{*}$ & Yes & Good \\
\hline Decker et al. & Yes & Yes & N/A & N/A & Yes & Yes & Yes & $\mathrm{N} / \mathrm{R}$ & Yes & Fair \\
\hline Zhang et al. & Yes & Yes & Yes & Yes & Yes & Yes & Yes & Yes & Yes & Good \\
\hline Hosoda et al. & Yes & Yes & $\mathrm{N} / \mathrm{A}$ & N/A & Yes & Yes & Yes & $\mathrm{N} / \mathrm{R}$ & Yes & Good \\
\hline Huang et al. & Yes & Yes & Yes & Yes & Yes & Yes & Yes & $\mathrm{N} / \mathrm{R}$ & Yes & Good \\
\hline Ren et al. & Yes & Yes & $\mathrm{N} / \mathrm{A}$ & N/A & Yes & Yes & Yes & $\mathrm{N} / \mathrm{R}$ & Yes & Good \\
\hline
\end{tabular}

*N/A not applicable, $N / R$ not reported $[12,14,16,19,23,24]$ 


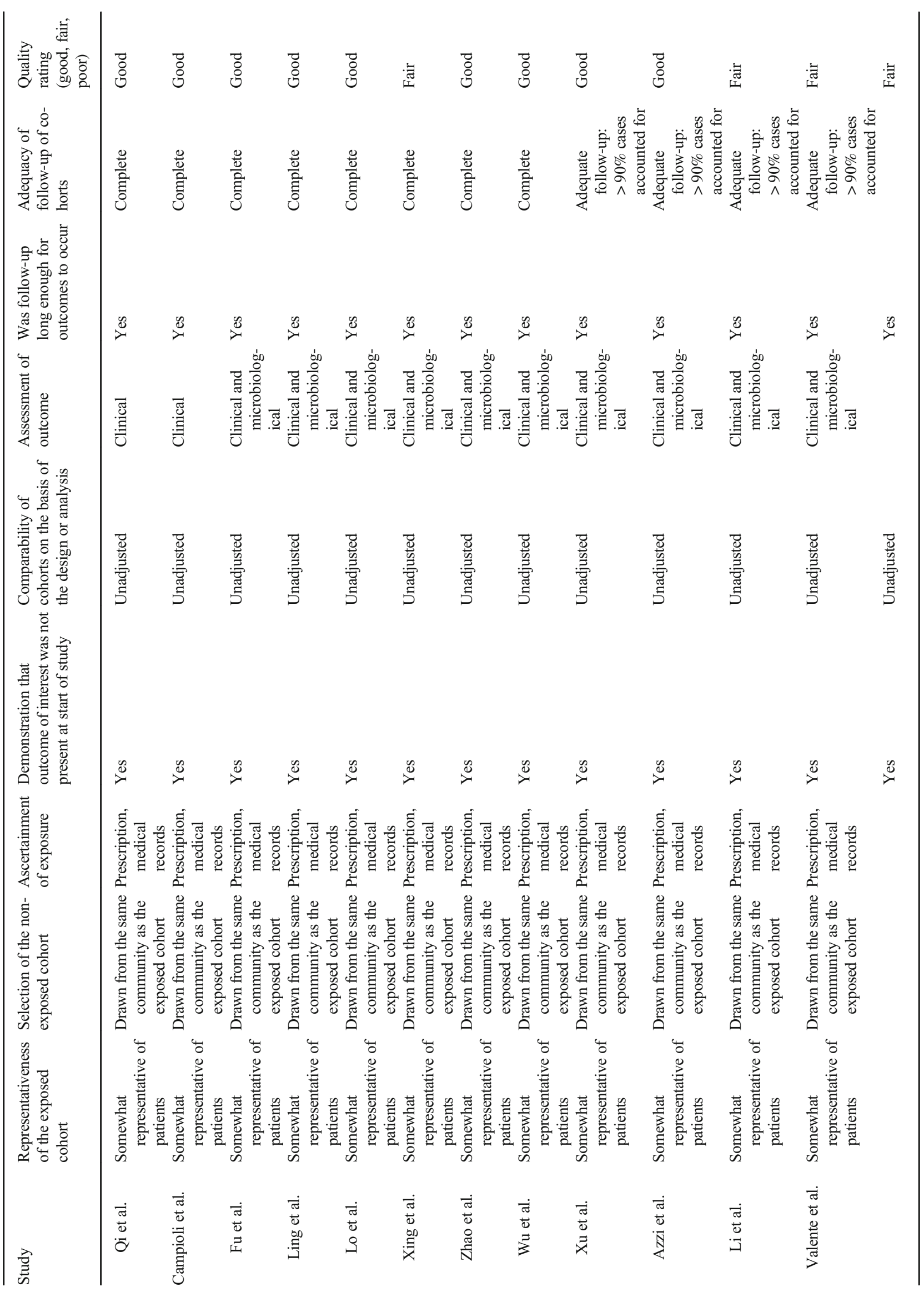


infectivity of the detected virus from the gastrointestinal tract would be needed to confirm the clinical implications of community transmission.

Detection of SARS-CoV-2 in the semen has raised concerns about transmissibility and sperm cryobanking as a possible propagator during the pandemic [40]. Li et al. identified 6 patients with detectable virus in the semen whereby 2 of these patients were in the clinical recovery phase [26]. Angiotensin-converting enzyme 2 (ACE2) receptor is expressed in large quantities in the testes and may explain the entry of the SARS-CoV-2 into the cells and subsequent detection in the semen [41].

In a prospective cohort study of 410 patients, albumin $\leq$ $35 \mathrm{~g} / \mathrm{L}$ was identified as a risk factor for prolonged viral shedding [13]. Aziz et al. found a statistically significant association between low albumin levels and severe COVID-19 in their meta-analysis of 910 patients [42]. Several studies have reported the trend of detectable Viral RNA for a longer period of time in the more severely ill patients of COVID-19 [10, 35, 43]. Hence, severity of disease can possibly be an effect modifier that modifies the effect of a low albumin level on the duration of viral shedding.

One of the key reasons for the WHO updating the discharge qualifying criteria of SARS-CoV-2 patients was detectable prolonged viral shedding, whereby the negative results were followed by the positive results [31]. This uncertainty in clinical decision-making can also result from sourced-based discrepancy in viral RNA detection. The study conducted by Azzi et al. on 25 patients who initially tested positive for viral RNA in saliva and nasopharyngeal swab alike, was followed by saliva testing that was positive in 2 patients, while nasopharyngeal swabs tested negative [25].

\section{Strengths}

Our review includes studies from across the world and takes epidemiological factors into account. It covers an extensive range of sources that have tested positive for SARS-CoV-2 and carry the possibility of risk of transmission. We have compared the more uncommon sources with the most commonly tested ones to outline the differences in timeline and guide clinical decision-making such as discharge and discontinuation of isolation procedures. Also, patient heterogeneity and patient-related factors such as comorbidities have been taken into consideration while analysing the duration of viral shedding.

\section{Limitations}

We recognize the limitations of our review. Despite performing a comprehensive literature search in wellestablished databases, independently conducted by two reviewers, and careful cross-referencing, the possibility of 
having missed a relevant study cannot be excluded. In addition, we acknowledge the limitations of the review methodology, such as search, selection, and publication biases.

\section{Conclusion}

Prolonged viral shedding is important to consider while discontinuing isolation procedures and/or discharging SARS-CoV-2 patients. Despite the lack of symptoms or resolution of the same, the risk of transmission persists due to viral shedding and cannot be easily disregarded. This risk varies in magnitude and depends on the infectivity of the virus, and also the patient population involved. Therefore, clinical-decision making should be governed by clinical scenario, guidelines, detectable viral load, source of detectable virus, infectivity, and patient-related factors.

Authors' Contribution RK conceived of the idea. RK reviewed the literature and collected the data with the help of SN. RK formulated the tables. $\mathrm{RK}$ and $\mathrm{SN}$ discussed the results and wrote the main draft of the manuscript.

\section{Compliance with Ethical Standards}

Conflict of Interest The authors declare that they have no conflict of interest.

Ethics Approval Not applicable.

Consent to Participate All authors had access to the data and equal role in writing the manuscript.

\section{References}

1. Surveillances $V$. The epidemiological characteristics of an outbreak of 2019 novel coronavirus diseases (COVID-19) — China, 2020. China CDC Weekly. 2020;2:113-22.

2. Transmission of SARS-CoV-2: implications for infection prevention precautions. World Health Organisation. Available from: https://www.who.int/news-room/commentaries/detail/ transmission-of-sars-cov-2-implications-for-infection-preventionprecautions. Accessed 5 Aug 2020.

3. Bai Y, Yao L, Wei T, Tian F, Jin D-Y, Chen L, et al. Presumed asymptomatic carrier transmission of COVID-19. JAMA American Medical Association. 2020;323:1406-7.

4. Hu Z, Song C, Xu C, Jin G, Chen Y, Xu X, et al. Clinical characteristics of 24 asymptomatic infections with COVID-19 screened among close contacts in Nanjing, China. Sci China Life Sci Springer. 2020;63:706-11.

5. Huang L, Zhang X, Zhang X, Wei Z, Zhang L, Xu J, et al. Rapid asymptomatic transmission of COVID-19 during the incubation period demonstrating strong infectivity in a cluster of youngsters aged 16-23 years outside Wuhan and characteristics of young patients with COVID-19: a prospective contact-tracing study. J Infect. Elsevier; 2020;

6. Le Chang LZ, Gong H, Wang L, Wang L. Severe acute respiratory syndrome coronavirus 2 RNA detected in blood donations. Emerg
Infect Dis Centers for Disease Control and Prevention. 2020;26: 1631.

7. Sun J, Zhu A, Li H, Zheng K, Zhuang Z, Chen Z, et al. Isolation of infectious SARS-CoV-2 from urine of a COVID-19 patient. Emerg Microbes Infect Taylor \& Francis. 2020;9:991-3.

8. Wang W, Xu Y, Gao R, Lu R, Han K, Wu G, et al. Detection of SARS-CoV-2 in different types of clinical specimens. JAMA. American Medical Association. 2020;323:1843-4.

9. Moher D, Liberati A, Tetzlaff J, Altman DG, Prisma Group. Preferred reporting items for systematic reviews and meta-analyses: the PRISMA statement. PLoS Med Public Library of Science. 2009;6:e1000097.

10. Qi L, Yang Y, Jiang D, Tu C, Wan L, Chen X, et al. Factors associated with duration of viral shedding in adults with COVID19 outside of Wuhan, China: A retrospective cohort study. Int J Infect Dis. Elsevier. 2020.

11. Campioli CC, Cevallos EC, Assi M, Patel R, Binnicker MJ, O'Horo JC. Clinical predictors and timing of cessation of viral RNA shedding in patients with COVID-19. J Clin Virol Elsevier. 2020;104577.

12. Li J, Zhang L, Liu B, Song D. Case report: viral shedding for 60 days in a woman with COVID-19. Am J Trop Med Hyg ASTMH. 2020;102:1210-3.

13. Fu Y, Han P, Zhu R, Bai T, Yi J, Zhao X, et al. Risk factors for viral RNA shedding in COVID-19 patients. Eur Respir J. Eur Respiratory Soc. 2020.

14. Decker A, Welzel M, Laubner K, Grundmann S, Kochs G, Panning $\mathrm{M}$, et al. Prolonged SARS-CoV-2 shedding and mild course of COVID-19 in a patient after recent heart transplantation. Am J Transplant. Wiley Online Library. 2020.

15. Ling Y, Xu S, Lin Y, Tian D, Zhu Z, Dai F, et al. The persistence and clearance of viral RNA in 2019 novel coronavirus disease survivors. Chin Med J.

16. Zhang N, Gong Y, Meng F, Shi Y, Wang J, Mao P, et al. Comparative study on virus shedding patterns in nasopharyngeal and fecal specimens of COVID-19 patients. Sci China Life Sci. Nature Publishing Group. 2020:1.

17. Lo IL, Lio CF, Cheong HH, Lei CI, Cheong TH, Zhong X, et al. Evaluation of SARS-CoV-2 RNA shedding in clinical specimens and clinical characteristics of 10 patients with COVID-19 in Macau. Int J Biol Sci. Ivyspring International Publisher. 2020;16:1698.

18. Xing Y. Prolonged viral shedding in feces of pediatric patients with coronavirus disease 2019. J Microbiol. Immunology and Infection. 2020;25.

19. Hosoda T, Sakamoto M, Shimizu H. Original: SARS-CoV-2 enterocolitis with persisting to excrete the virus for about two.

20. Zhao F, Yang Y, Wang Z, Li L, Liu L, Liu Y. The time sequences of oral and fecal viral shedding of coronavirus disease 2019 (COVID-19) patients. Gastroenterology. Elsevier. 2020.

21. Wu Y, Guo C, Tang L, Hong Z, Zhou J, Dong X, et al. Prolonged presence of SARS-CoV-2 viral RNA in faecal samples. The lancet gastroenterology \& hepatology. Elsevier. 2020;5:434-5.

22. $\mathrm{Xu} \mathrm{Y,} \mathrm{Li} \mathrm{X,} \mathrm{Zhu} \mathrm{B,} \mathrm{Liang} \mathrm{H,} \mathrm{Fang} \mathrm{C,} \mathrm{Gong} \mathrm{Y,} \mathrm{et} \mathrm{al.} \mathrm{Characteristics}$ of pediatric SARS-CoV-2 infection and potential evidence for persistent fecal viral shedding. Nat Med Nature Publishing Group. 2020;26:502-5.

23. Huang R, Zhao H, Wang J, Yan X, Shao H, Wu C. A family cluster of COVID-19 involving an asymptomatic case with persistently positive SARS-CoV-2 in anal swabs. Travel Med Infect Dis. Elsevier. 2020.

24. Ren J, Li D, Wang C, Wu J, Wang Y, Sun Y, et al. Positive RT-PCR in urine from an asymptomatic patient with novel coronavirus 2019 infection: a case report. Infect Dis Taylor \& Francis. 2020:1-4. 
25. Azzi L, Carcano G, Gianfagna F, Grossi P, Dalla Gasperina D, Genoni A, et al. Saliva is a reliable tool to detect SARS-CoV-2. J Infect. Elsevier. 2020

26. Li D, Jin M, Bao P, Zhao W, Zhang S. Clinical characteristics and results of semen tests among men with coronavirus disease 2019 . JAMA Netw Open American Medical Association. 2020;3: e208292-2.

27. Valente P, Iarossi G, Federici M, Petroni S, Palma P, Cotugno N, et al. Ocular manifestations and viral shedding in tears of pediatric patients with coronavirus disease 2019: a preliminary report. J Am Assoc Pediatr Ophthalmol Strabismus. Elsevier. 2020.

28. Güemes-Villahoz N, Burgos-Blasco B, Arribi-Vilela A, ArriolaVillalobos P, Vidal-Villegas B, Mendez-Fernandez R, et al. SARS-CoV-2 RNA detection in tears and conjunctival secretions of COVID-19 patients with conjunctivitis. J Infect. Elsevier. 2020.

29. Quality Assessment Tool for Case Series studies. National Heart, Lung, and Blood Institute. Available from: https://www.nhlbi.nih. gov/health-topics/study-quality-assessment-tools.

30. Stang A. Critical evaluation of the Newcastle-Ottawa scale for the assessment of the quality of nonrandomized studies in meta-analyses. Eur J Epidemiol Springer. 2010;25:603-5.

31. Clinical management of COVID-19- Interim guidance. World Health Organisation; 2020. Available from: https://apps.who.int/ iris/bitstream/handle/10665/332196/WHO-2019-nCoV-clinical2020.5-eng.pdf?sequence=1\&isAllowed=y. Accessed 5 Aug 2020 .

32. Laboratory testing of human suspected cases of novel coronavirus $(\mathrm{nCoV})$ infection -Interim guidance. World Health Organisation; 2020. Available from: https://apps.who.int/iris/bitstream/handle/ 10665/330374/WHO-2019-nCoV-laboratory-2020.1-eng.pdf. Accessed 5 Aug 2020

33. Cheng H, Jian S, Liu D, Ng T, Huang W, Lin H. Taiwan COVID19 outbreak investigation team. Contact tracing assessment of COVID-19 transmission dynamics in Taiwan and risk at different exposure periods before and after symptom onset. JAMA Intern Med. 2020 (epub 1 May 2020). 2020.

34. Zhu L, Gong N, Liu B, Lu X, Chen D, Chen S, et al. Coronavirus disease 2019 pneumonia in immunosuppressed renal transplant recipients: a summary of 10 confirmed cases in Wuhan, China. Eur Urol. Elsevier; 2020.
35. Wölfel R, Corman VM, Guggemos W, Seilmaier M, Zange S, Müller MA, et al. Virological assessment of hospitalized patients with COVID-2019. Nature Nature Publishing Group. 2020;581:465-9.

36. Laboratory biosafety guidance related to coronavirus disease (COVID-19)- Interim guidance. World Health Organisation. 2020. Available from: https://www.who.int/publications/i/item/ laboratory-biosafety-guidance-related-to-coronavirus-disease(covid-19). Accessed 5 Aug 2020.

37. Arons MM, Hatfield KM, Reddy SC, Kimball A, James A, Jacobs JR, et al. Presymptomatic SARS-CoV-2 infections and transmission in a skilled nursing facility. N Engl J Med. Mass Medical Soc; 2020.

38. Xiao F, Tang M, Zheng X, Liu Y, Li X, Shan H. Evidence for gastrointestinal infection of SARS-CoV-2. Gastroenterology Elsevier. 2020;158:1831-3.

39. Parasa S, Desai M, Chandrasekar VT, Patel HK, Kennedy KF, Roesch T, et al. Prevalence of gastrointestinal symptoms and fecal viral shedding in patients with coronavirus disease 2019: a systematic review and meta-analysis. JAMA Network Open American Medical Association. 2020;3:e2011335-5.

40. Yakass MB, Woodward B. COVID-19: should we continue to cryopreserve sperm during the pandemic? Reprod Biomed Online Elsevier. 2020;40:905.

41. Gheblawi M, Wang K, Viveiros A, Nguyen Q, Zhong J-C, Turner AJ, et al. Angiotensin-converting enzyme 2: SARS-CoV-2 receptor and regulator of the renin-angiotensin system: celebrating the 20th anniversary of the discovery of ACE2. Circ Res Am Heart Assoc. 2020;126:1456-74.

42. Aziz M, Fatima R, Lee-Smith W, Assaly R. The association of low serum albumin level with severe COVID-19: a systematic review and meta-analysis. Crit Care. 2020;24:255.

43. Xu K, Chen Y, Yuan J, Yi P, Ding C, Wu W, et al. Factors associated with prolonged viral RNA shedding in patients with COVID19. Clin Infect Dis. 2020.

Publisher's Note Springer Nature remains neutral with regard to jurisdictional claims in published maps and institutional affiliations. 